\title{
“God Save the Queen”: Narrating Nationalism and Imperialism in Quebec on the Occasion of Queen Victoria's Diamond Jubilee
}

\section{Karen Stanworth}

Volume 21, numéro 1-2, 1994

Représentation et identités culturelles

Representation and Cultural Identity

URI : https://id.erudit.org/iderudit/1072667ar

DOI : https://doi.org/10.7202/1072667ar

\section{Aller au sommaire du numéro}

\section{Éditeur(s)}

UAAC-AAUC (University Art Association of Canada | Association d'art des universités du Canada)

\section{ISSN}

0315-9906 (imprimé)

1918-4778 (numérique)

\section{Découvrir la revue}

Citer cet article

Stanworth, K. (1994). "God Save the Queen”: Narrating Nationalism and Imperialism in Quebec on the Occasion of Queen Victoria's Diamond Jubilee. RACAR : Revue d'art canadienne / Canadian Art Review, 21(1-2), 85-99. https://doi.org/10.7202/1072667ar

\section{Résumé de l'article}

Les fêtes du Jubilé de la reine Victoria, en 1897, doivent être considérées comme des stratégies désignées à renforcer l'identification de la Reine à la nation. Les nombreuses ovations dont elle fait l'objet à travers l'Empire britannique suggèrent une cohésion impériale aux célébrations du Jubilé qui réduit la complexité des structures narratives sous-jacentes. En nous penchant sur un seul exemple, cet article examine les récits visuels et textuels du fascicule, Souvenir du Jubilé de Québec (1897). L’analyse structurale du livret permet de retrouver les traces d'une archéologie visuelle des récits à travers les diverses couches de signification. Outre le texte racontant l'histoire du règne de Victoria, il existe trois ou quatre autres histoires qui peuvent retenir l'attention du lecteur. Elles sont construites par le positionnement répétitif de la publicité, des portraits, des vues urbaines et des autres images. Nous pensons que les mots et les images ont été consciemment organisés pour renforcer la légitimité de l'ordre impérial. Cependant, les variations mineures du schéma, les juxtapositions, les séquences et les élisions apparemment inconscientes mettent à jour des écarts quant à la pensée dominante qui sous-tend le discours du Jubilé. Les nuances dans ces récits divergents pourraient peut-être permettre d'y inscrire la voix « sub-alterne » des Canadiens français au moment même où ils semblent adhérer au discours de la Couronne.
Tous droits réservés @ UAAC-AAUC (University Art Association of Canada | Association d'art des universités du Canada), 1996
Ce document est protégé par la loi sur le droit d'auteur. L'utilisation des services d’Érudit (y compris la reproduction) est assujettie à sa politique d'utilisation que vous pouvez consulter en ligne.

https://apropos.erudit.org/fr/usagers/politique-dutilisation/ 


\title{
"God Save the Queen": Narrating Nationalism and Imperialism in Quebec on the Occasion of Queen Victoria's Diamond Jubilee
}

\author{
KAREN StANWORTh, York University
}

\section{Résumé}

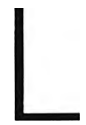

es fêtes du Jubilé de la reine Victoria, en 1897, doivent être considérées comme des stratégies désignées à renforcer l'identification de la Reine à la nation. Les nombreuses ovations dont elle fait l'objet à travers l'Empire britannique suggèrent une cohésion impériale aux célébrations du Jubilé qui réduit la complexité des structures narratives sous-jacentes. En nous penchant sur un seul exemple, cet article examine les récits visuels et textuels du fascicule, Souvenir du Jubilé de Québec (1897). L'analyse structurale du livret permet de retrouver les traces d'une archéologie visuelle des récits à travers les diverses couches de signification. Outre le texte racontant l'histoire du règne de Victoria, il existe trois ou quatre autres histoires qui peuvent retenir l'attention du lecteur. Elles sont construites par le positionnement répétitif de la publicité, des portraits, des vues urbaines et des autres images. Nous pensons que les mots et les images ont été consciemment organisés pour renforcer la légitimité de l'ordre impérial. Cependant, les variations mineures du schéma, les juxtapositions, les séquences et les élisions apparemment inconscientes mettent à jour des écarts quant à la pensée dominante qui sous-tend le discours du Jubilé. Les nuances dans ces récits divergents pourraient peut-être permettre d'y inscrire la voix «sub-alterne» des Canadiens français au moment même où ils semblent adhérer au discours de la Couronne.
1 he Queen's Jubilee celebrations of 1897 were purposeful strategies designed to solidify Victoria's identification as the nation, not just of the nation. As Dorothy Thompson puts it, "the increase of empire and the increase of royal pomp and ritual went naturally together, and the queen went along with both processes willingly." "British imperial rhetoric silenced republican criticisms of the monarchy in England while Canadian liberalism sought to ratify its foreign and domestic policies through appeals to the humanism of British parliamentary procedures. ${ }^{2}$ It is the overwhelming scale of these festivities, their global expanse and expense, which suggests an enormous mobilization of resources and personal energies was undertaken to ensure their success. Although there were minor voices of discord in Britain, ${ }^{3}$ these were drowned in the outpouring of sentiments of delight and demonstrations of loyalty. Adding their voices to the many, the citizenry of Quebec swore fealty and devotion to their monarch. Newpapers, poems, memorabilia, and personal accounts of the Jubilee celebrations in Quebec repeated messages of good tidings to the Queen alongside exclamations of loyalty and pride on the part of the French Canadians. ${ }^{4}$

The many ovations to the longevity, generosity, and sagacity of the Queen appearing across the globe in the many languages of the British Empire suggest a solidarity or an Imperial cohesion to the Jubilee celebrations which seems suspect if only for its apparent universalism. In this paper I question that universalism as part of my ongoing research into the visual rhetoric employed in the articulation of national identities in nineteenth-century Canada. Here, I attempt to deconstruct the complex narrative structures which affirm the seemingly uniform representations of joy and unrequited devotion to the throne in 1897 . In order to open up the ways in which the narrative of universal loyalty functions, I examine an apparently minor element in the spectacular enactment of Jubilee Day, the Quebec Jubilee Souvenir Number, a souvenir booklet produced in Quebec City in 1897.5 I question how it is that this souvenir booklet carries contradictory, yet satisfying, meanings to French-Canadian readers whose needs may appear incompatible with those of Britain's monarchy, and of its parliament. Structural analysis of the booklet traces the visual archaeology of the narratives along and across complex layers of meaning. As in an archaeological dig, the sedimented cross-sections are rarely absolutely distinct one from another. Words and images, I argue, are arranged selfconsciously to reinforce stability, equality and the confidence of order. However, it is the minor variations in the schema, the apparently unconscious juxtapositions, sequences, and elisions, which reveal the challenges to the dominant narrative of the Jubilee and which disclose the impossibility of establishing distinct narratives. This is not a story of purely national, ethnic, class or gender tensions. ${ }^{6}$ In what follows, I will examine how the ordering of the document confirms its memorializing function and how the slight diversions from the authorized story suggest other meanings which threaten to displace that story's hegemony.

The significance of the booklet lies, I will argue, in its constituent narratives, that is, in its story lines, both verbal and visual. In addition to the use of a written text to recount the story of the Queen's reign, there are arguably three or four other stories vying for the reader's attention and which, depending on who is reading, and when, may take precedence over the authoritative monarchical tale. These are constructed through the reiterative placement of advertising, portraits, city views and other images in the 
booklet. I have identified these texts as the visual biography of the Queen, the visual biography of Quebec City, the advertisementbased record of liberal progress in the city, and the doubled, yet not separate, French and English versions of the principal written text, the story of the Jubilee. Although it is admitedly somewhat arbitrary to delineate these storylines separately, it is particularly important to recognize the ways in which the presentation of illustrations can construct continuity of narrative through thematic reiteration. The images function not merely to illustrate a passage or page of text, but in and of themselves create new visual texts which have the capacity to extend, contradict or mediate the meanings contained in the words. I will briefly describe what I mean by each of these designations and will then discuss the ways in which they intersect and reconstruct each other.

The Narratives:

Queen, Home, and Country

A celebration of the sixtieth year of Queen Victoria's reign, the Quebec Jubilee Souvenir Number contains within its illustrated pages one primary text of five recto pages describing the sixty-year reign. The verso pages contain local advertising. Illustrations appear on most pages. These are followed by more advertising and two pages of written text, one concerned with the Jubilee celebrations in London and one with the life of Victoria as

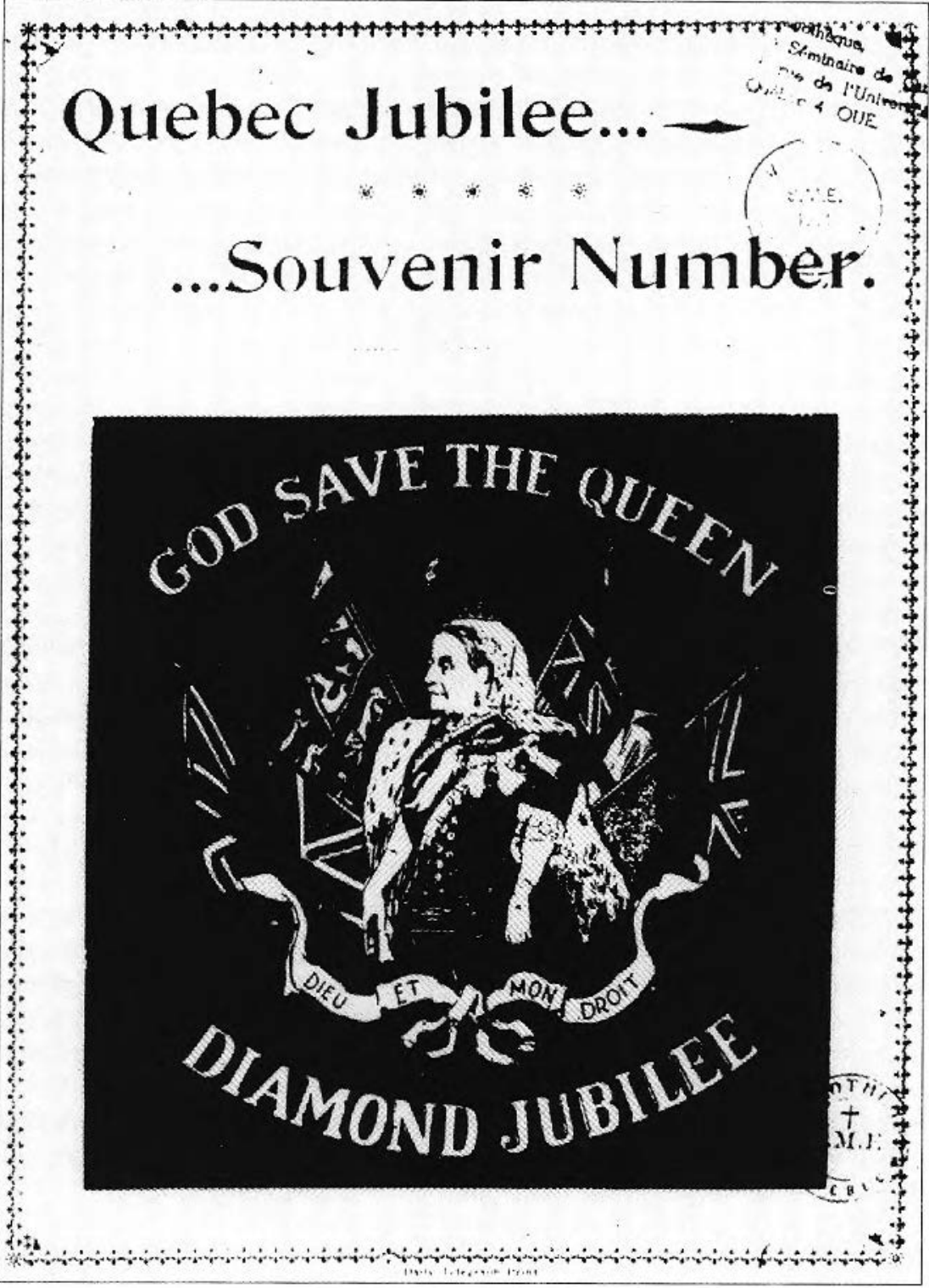
a child. The booklet organizes the queen's life story, that of the Empire, and that of the colony around a developmental model which naturalizes events into a discourse of human evolution. This biographical perspective, as we shall see, feeds into the widely accepted notion of progress as inevitable and desirable. Global expansion, national development and local progress re-enact the benefits of aging, moving from youth to wise old age. Decrepitude and indulgence are not implicated here.

The Jubilee Souvenir Number presents the biography of the Queen as both visual and verbal. The front cover, with its schematic portrayal of the Queen regnant surrounded by the flags of her dominions, presents her as would an emblem book with title and motto confirming the to-

tality of God, Queen and Country, (fig. 1). The story of the Queen as woman and monarch begins with representations of her father and mother positioned above an image taken at the time of her succession to the throne (pg. 5, fig. 4). The following page illustrates the Queen at eight, fifteen and twenty-two years of age. Other images portray her at her coronation, as a young wife, as a widow, and in her Jubilee regalia. ${ }^{7}$ Ending with "the latest portrait of the Queen," the visual biography presents the normative events of a life: the expected sequence of tragedy, celebration and perseverence. ${ }^{8}$ This visual story is extended by illustrations of the royal residences which literally frame the Queen's biography, appearing as they do at the beginning and the end of the narrative of her person. 
Figure 2. Quebec Jubilee Souvenir Number, (Quebec, 1897), pages i-I (Photo: John Briggs).

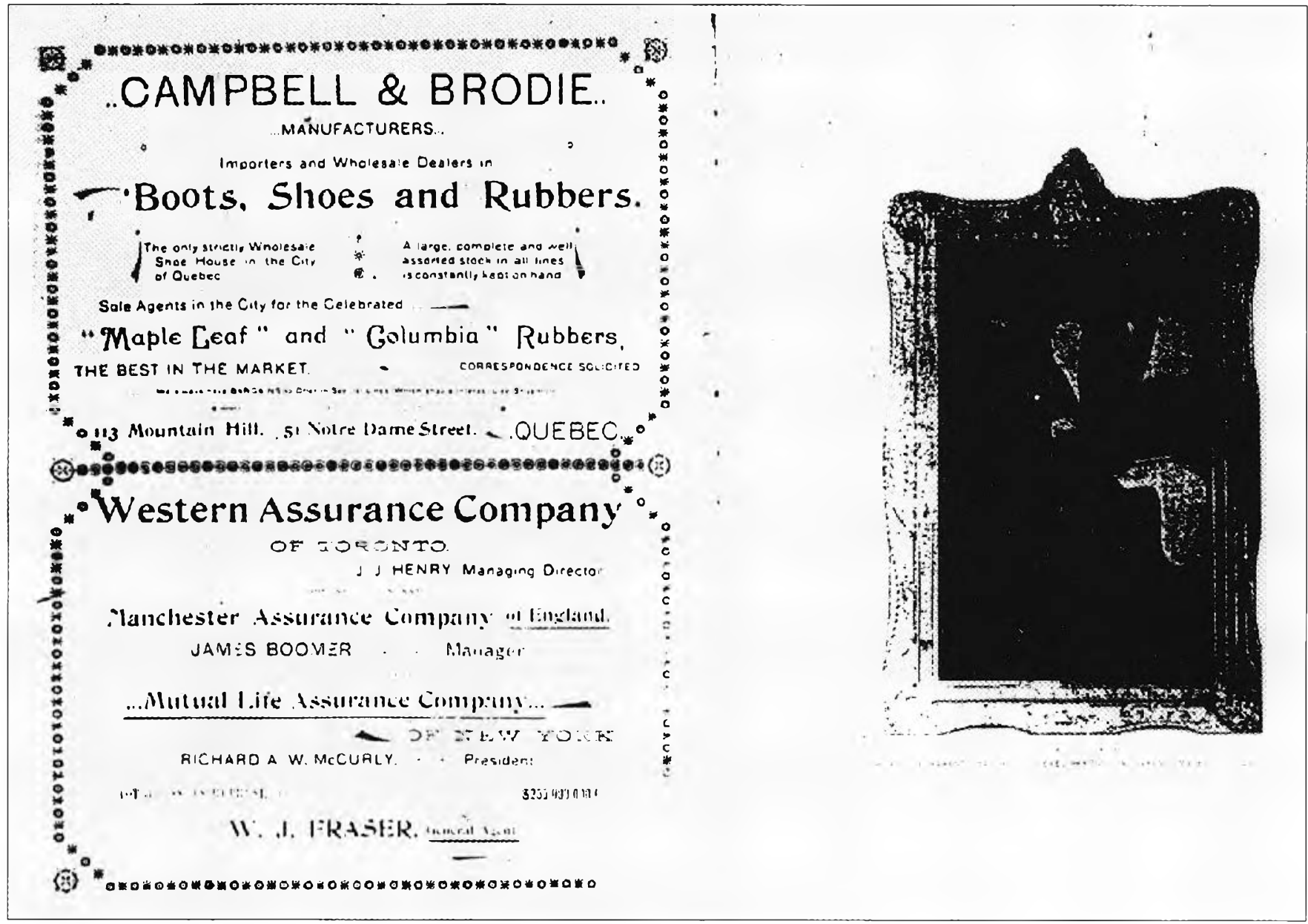

The second visual narrative is that of the city of Quebec itself. Juxtaposed against the biography of the Queen is the counter-story of the Mayor, the Honourable SimonNapoléon Parent, and his dominion. The full-length image of the Mayor, which was virtually as indistinguishable in the original booklet as it is in reproduction (fig. 2), was, nevertheless, instantly recognizable. Everyone was totally familiar with the popular Mayor. Located on page one, the portrait - painted a year earlier by Robert L. Wickenden ${ }^{9}$ on a commission from the city council, "to underline the numerous improvements which had been accomplished during [Parent's] administration of the municipality" 10 is seen to commence the story of the Jubilee in Quebec. If the image of the Queen on the cover is understood to function as an emblem of British sovereignty, then it is the Mayor who first claims attention as being fully present in the reader's physical reality. The corporeality of the mayor, that is, his bodily immediacy and historical presence, is opposed to the schematic representation of the Queen and reinforces the lived reality of Quebec's citizenry. It is Parent who administers the benefits of the celebrated British liberties in this town. In the portrait, Parent is depicted with his arm gesturing to indicate the new City Hall, which is the institutional forum of his administration. That power is located in and through the Mayor's representative and literal office is further emphasized in the judicious placement of a similar view of "The City Hall - L'Hôtel de Ville" on the verso of the page depicting Parent. The grand City Hall was completed during Parent's tenure as mayor and had been officially opened nine months before the publication of the booklet. It is thus the Mayor's official site of power which prefaces the Queen's biography. The exploitation of the verso pages to illustrate the other institutions of local authority is surely not accidental. The Roman Catholic Basilica and the Anglican Cathedral, the military gates and the martello tower are represented on these pages. Likewise, the ancien régime is signalled by the illustrations of the landing of Jacques Cartier and of the Château Louis. In arguing that the Mayor's body represents or stands in for the specificity of the local as opposed to the distance of the imperial, I am suggesting that the story of the Queen is rationalized and made tangible in the evidence that local 
Figure 3. Quebec /ubilee Souvenir Number, (Quebec, 1897), pages 2-3 (Photo: John Briggs).

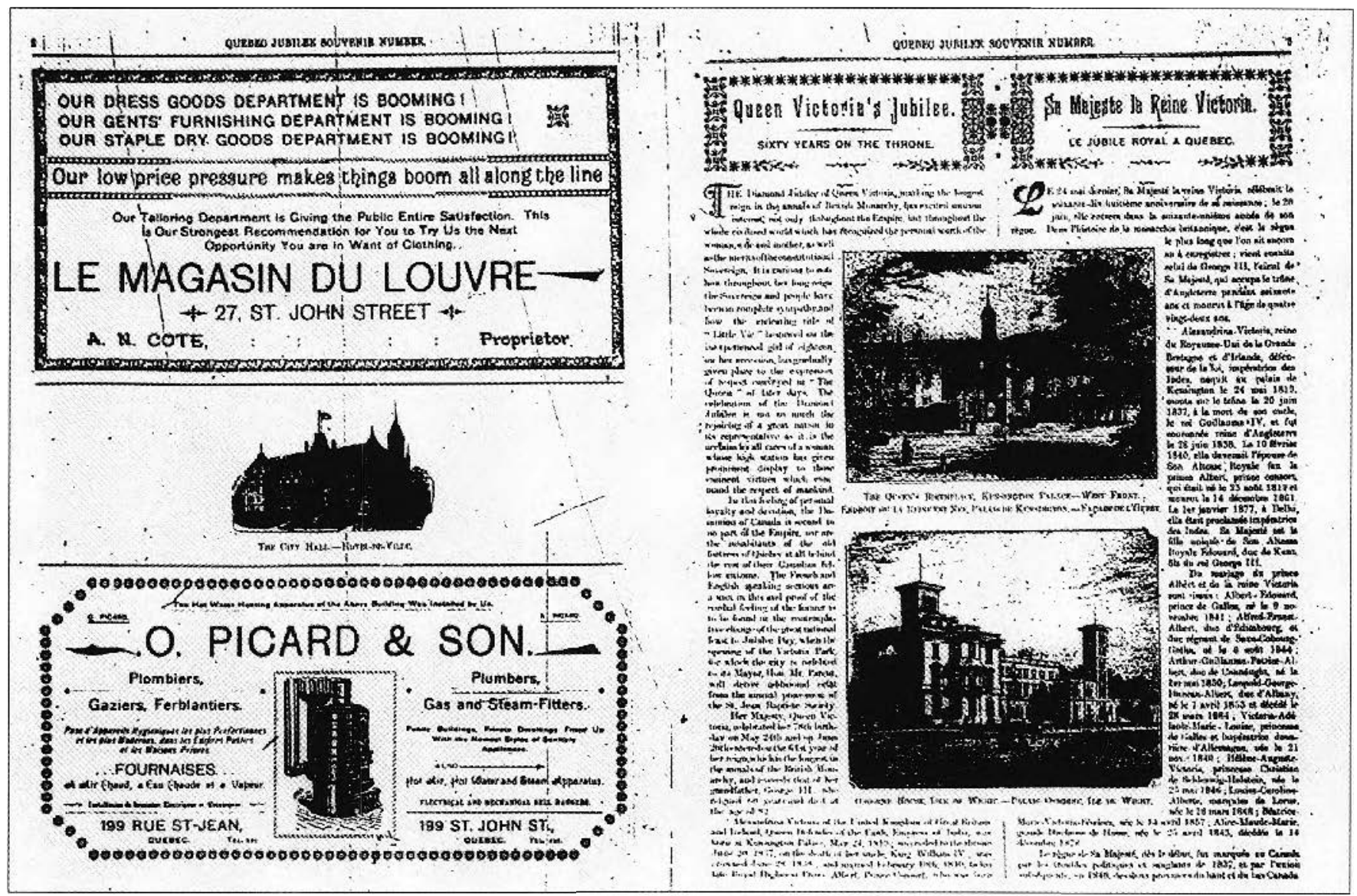

accomplishments provide for the success of the monarchy and the Empire.

This kind of sequence of emblemata of Empire (the cover image), followed by full-figure photo (of the Mayor), followed by photographs and prints of the Queen's life, is similarly present in the souvenir brochure produced by Montreal for the Jubilee celebrations. None of the other souvenir booklets produced across Canada at the time followed this sequence. What we may be seeing here is the necessity of placing the mayors of Montreal and Quebec into a specific relationship to the Empire. Both mayors would have faced the ongoing tension between local economic factions (sometimes divided on nationalist grounds, sometimes according to class, industry, or other economic interest). The need constantly to prevaricate between Britishness and local interests is arguably more intense in the French/English environment than in the predominantly English locale. Given the visual evidence of the schema and the real differences faced by the mayors, it seems possible that the body of the Mayor was meant to provide an entry point for the local reader into the Jubilee story. The choice of portrait mode does not merely conform to conventional genres but appropriates the most significant form for the beginning of the story. They frame the narrative. The cover does not use widely available photographs of the Queen but rather employs a schematic device which repeats the reductive, easily read/viewed images of the flags and print. Certainly, the image of the mayor is a standard full-length portrait. However, the more common bust image, typical of frontispieces and other advertising ephemera, ${ }^{11}$ is not adopted for this booklet. It is the full-length figure who is portrayed here (and in the Montreal booklet). Given this, and the supporting "portraits" of the city sites, I am suggesting that the narrative of the city was meant to facilitate the reading of the local in conjunction with the story of the Queen.

The third major visual field is that of the advertisements. These occupy the verso pages and run continuously throughout the body of the booklet. The alternation of English and French advertisements seems quite conspicuously to parallel the English, then French, of the header on each page: "Quebec Jubilee Souvenir Number" heads each page of advertisements while "Numéro Souvenir du Jubilé de Québec" surmounts each page of text. The careful bal- 
ance is evident in the symmetry of design which is consistent nearly to the point of predictability. This sense of balance is equally evident in the written summary of the Queen's sixty years on the throne.

Just as the images of Victoria at ages eight through seventy-eight narrate, in their serial format and linear progression, the "natural" story of a young girl's maturation from child to matriarch, so the simultaneous evolution of the United Kingdom from nation state to imperial force is described in words. Through a detailed review of the improvements in all manner of economic, judicial and territorial arenas as achieved in the sixty years of Victoria's reign, Nazaire LeVasseur writes the verbal counterpart to the biography of the Queen and the visual biography of Quebec City. ${ }^{12}$ Just as the Queen matured and her dominion expanded, so too is Canada portrayed as having attained maturity in the sixty years between 1837 and 1897 .

In tracing these narrative lines, visual and verbal, I have been attempting to follow what can be understood as the sub-plots of a novel - a novel which relies upon the readers' belief in the inherent truthfulness of the history which has been disclosed to them. These separate visual and verbal histories, of the Queen, of the city, of the country, are not meant to be read as discrete commentaries but as a totality. Once integrated into the Jubilee Souvenir Number, they re-present the disparate events of local, national, and imperial history as a cohesive history. The closure imposed upon the interpretation of these events through the linear and progressive model of storytelling can be understood as implicity moralizing. Hayden White has argued that history can be understood as a totalizing narrative shaped through the moral rhetoric of the storyteller. ${ }^{13}$ Peter Stallybrass and Allon White have suggested, in their study. of the transgressive potential of high/low conflict in text, that simultaneous narratives may not always maintain the hegemonic control of the authorized version of events. ${ }^{14}$ In considering the implications of White's moralizing history and the dichotomies of Stallybrass and Allon White, I have found that the multiplicity of the narratives in the Jubilee booklet are not as monolithic as the former position would imply, nor as oppositional as the latter. Rather, their efficacy lies in the interstices between each of them. It may be that the notion of a sub-altern voice as proposed by Homi Bhabha provides a theoretical framework within which the simultaneous narrative of the Jubilee booklet can be understood to function. ${ }^{15}$ It is as a consequence of considering the implications of Bhabha's post-colonial theory that I have come to see that the voice of French-Canadians should not be understood as absent from the imperialist texts. Not only is it plausibly present, it is also multiple in itself. I will argue that this complexity can be opened up through a careful examination of the narrative lines of the text which occasionally fracture the smooth surface of the Jubilee Souvenir Number which they also serve to construct.

With precise symmetry of presentation, the parallel but not exactly bilingual accounts of the life of the Queen and her subjects differ in small, yet significant, detail. The gaps, absences and emphases in the parallel texts suggest that the French and English write this story differently. It seems that the slight breaks in symmetry provide an overt instance of fracture which may direct the informed reader to a means of rationalizing the discourse while permitting the dominant narrative to remain uncontested. If we return to the pages of the Jubilee text, we can begin to open up the hermeneutic resolution of its totality by placing local politics over and against those of the country and the Empire.

Re-reading the Narratives

As I suggested in my discussion of the visual biography of the Queen, the first image of Victoria functions emblematically as a suitable framing device for the text as a whole but it does not present a bodily reality. Rather, the body of the mayor, in the full-length portrait of Simon-Napoléon Parent, is the first to be figured mimetically (fig. 2). Placed before the Queen's story (fig. 4), the physical immediacy of Parent is reinforced by the highest institutional authority in the physical experience of the readers, i.e. the recently opened City Hall. The Mayor was known locally as "le maire des grands travaux" (the mayor of large public works) - a Jean Drapeau of 1890 s Quebec. ${ }^{16}$ Closely aligned with Prime Minister Wilfrid Laurier and his Liberal progressives, Parent had just been appointed President of the Compagnie du Pont de Québec. He was to be publicly commended in the next few years for his expansionist policies in the domains of construction, tramway development, and the Louise Basin extension. These were the very sorts of activities which LeVasseur, the author of the Jubilee text, had identitifed as crucial to the aggrandizement of the French nation - as is evidenced by the flowering of the French language described in his futuristic story about the Quebec Carnival of 1996.

LeVasseur wrote this story sometime in the mid-1890s and in hindsight it seems to be pure fantasy. He wrote, "[T]he fact is that, in the 1990s, in Toronto and in many other towns in Ontario, as well as the Eastern United States, the English language has almost completely faded away. French has become the language of social, political, and financial relations." 17 His narrator declared that the strengthening of the French language commenced in the 1890s and 
led inevitably to the unprecedented expansion of the French element in Canada. It was the possibility of that outcome as perceived by LeVasseur and his audience which made his futuristic story centred on the 1996 Quebec Carnival at all plausible. The same socio-economic factors of 1890s Quebec which LeVasseur used to validate his predictions underline my account of la patrie and the Jubilee celebrations of 1897.

LeVasseur's story was written in the 1890s, was probably published in a local paper, and reappeared in a collection of short stories in $1920 .{ }^{18}$ Employing the authorial device of projection, the narrator provides an overview of a century's progress from 1890 to 1990 as recounted by a young Frenchman who was visiting Quebec for the first time. On his transatlantic voyage, the Frenchman meets le vieillard, an elderly Quebecois, who remains enigmatically unnamed throughout the story. Through le vieillard's account of Quebec's history, LeVasseur details the benefits which have accrued to the province over the last century. Progress, represented by extensive train networks, advanced communications and the widespread use of electricity, is seen as the direct consequence of the judicious use of Quebec's natural resources, both human and physical.

The same themes resonate throughout the visual narratives of the Jubilee Souvenir Number and serve to confirm the contemporary success of Quebec's Liberal nationalists and, of course, their economic self-interest. After all, the authors of the advertising text, the businessmen of Quebec, did pay for their privilege to announce their goods and services in proximity to those of the Crown. Just as the visual narrative of the local biography can be seen to be placed opposite that of the Queen, suggesting a not quite respectful claim for equal billing, so too the verbal text transgresses the expectations of its bilingualism. The assumption of the reader of one language is that the same content is represented in the parallel written text, but the relationship here is nor one of perfect symmetry. The minor differences between the two versions are underscored by the realization that the celebration of sixty years of Victoria's reign also coincides uncomfortably with the sixtieth anniversary of the Rebellion of Lower Canada in 1837. In the English version of the text delineating the "Sixty Years on the Throne," LeVasseur notes that the opening years of Her Majesty's reign were "marked by the rebellion in Canada." The parallel text, structured to physically echo the layout of the English text (fig. 3), is presented under the title, "Le jubilé royal à Québec". This title, with its emphasis on the experience of the Jubilee at a specific moment in time and in a particular space, immediately re-situates the French readers. It removes them from a symbolic (yet real) relationship with the monarch to a lived experience of that monarchy. It is this local reality which sustains the cries of "God Save The Queen," voiced by English and French alike. ${ }^{19}$ It is a relationship which is realized and re-politicized through the mayoralty of Parent, whose progressive position is itself sustained through British political institutions emblematized by the Queen. Furthermore, in the French version of the early years of the reign, LeVasseur refers to the period of Victoria's ascendency as "marquée au Canada par les troubles politiques et sanglants" (p.15). The "political and bloody troubles" of Lower Canada mark the first years of contact between the French in Canada and the Queen. The revolt in Upper Canada is not mentioned in French while in English the two uprisings are subsumed into a single rebellion. The choice of LeVasseur's words could not have been a question of chance - not in the public language of a man who championed the French language, and indeed, who prophesied its ascendency. ${ }^{20}$ What this obvious point of departure from the assumed bilingualism of the publication signals is the transgressive potential of the non-conforming text. The design of the pages, carefully balanced in visual and textual layout, suggests that the contents of the visual and verbal texts mirror each other, that the English text means what the French version means, and that the visual texts are identical. However, the references to the formative years of Victoria's reign in Canada in French and in English are linguistically as well as culturally far from synonymous, and public memory appears to be socially constituted as different depending upon whether one is identified as being of French or English heritage.

LeVasseur further complicates the relationship between the English-and French-language texts by moving a small paragraph regarding the Mayor and the Jubilee festivities from the first page, where it appears in English, to the last page, where it appears in slightly altered form in French. In French, he omits to mention that the St. Jean Baptiste Society will participate in the official opening of Victoria Park - a park which Parent had insisted be named in the Queen's honour despite the fact that the city councillors had intended it be named after Parent himself. ${ }^{21}$ Local politics merge with the national and the imperial in LeVasseur's arguably purposeful omission. I will return later to some of these relations, but of immediate significance in Parent's seeming act of humility is the way in which his gesture linked him directly to the Queen. Parent's success in arranging the opening of Victoria Park on Jubilee Day resulted in the double triumph of having the province's Lieutenant Governor in attendance at the Jubilee celebrations of June 22, 1897 in Quebec and not in Montreal. The rivalry between $Q$ uebec and Montreal ${ }^{22}$ was possibly at the 
root of Parent's efforts to ensure that the Lieutenant Governor, Adolphe Chapleau, was on hand to open the Park. Parent took on Lomer Gouin, the Mayor of Montreal, and won; Chapleau even stayed in town long enough to hold an open house at Spencer Wood at which "all of Quebec's best society [was] doubtless present to enjoy the splendid hospitality of Sir Adolphe and his estimable lady." 23 Mayor Parent had also initiated the request to the St. Jean Baptiste Society's provincial representatives to support his request to move the annual St. Jean Baptiste Day celebrations from the 24 th of June to the 22 nd so that they would coincide with the Jubilee celebrations. ${ }^{24}$

I thought at first that the small counter-textual insertions and negative evidence provided by LeVasseur's omissions suggested that the grand narrative of the Jubilee Souvenir Album concerning the blessings of constitutional monarchy had been effectively transgressed by what Stallybrass and White might have called the voice from below. However, in light of the subtleties of LeVasseur's manoeuvres and the fact that he, too, was acting within the Liberal agenda by accepting a position as the Consul for Brazil in Canada, it seems that we have to consider that the apparent contradictions were not irreconcilable at that moment in time, in that particular place. The discours de circonstance, two speeches delivered by the Hon. Mr. Duffy, Commissioner of Public Works, and by the Hon. J.E. Robidoux, Provincial Secretary, at the opening ceremonies of Victoria Park suggest the elasticity of the concept informing the universal cry, "God Save the Queen." That the English could read the multiple narratives as supportive of the idea that the French were indeed subjects of the English crown is evident in Duffy's speech. Read in English, after the Mayor and the Lieutenant-Governor had spoken in French, Duffy's speech was summarized in the French-language press (and not reprinted in full in any English-or French-language newspaper of the day). ${ }^{25}$ In what appears to be Duffy's first address to the citizens of Quebec, he praises the benefits of the English flag; that is, wherever the flag has gone, so, too, have appeared the benefits of the English constitution which has enabled progress in the arts, sciences, and commerce. Although he acknowledges that "we" are the children of France and England (as a consquence of the "glorious battle of the Plains of Abraham"), "Canada which is today so prosperous owes everything to England." 26

The French-Canadian audience (largely unilingual, as were the majority of the English-speaking residents of Quebec) had the opportunity to hear the rest of the speeches in French. Several of these were reprinted in the local press both in French and translated into English. It is in the speeches of Mayor Parent, Lieutenant-Governor Chapleau and, especially that given by Robidoux, that the specificity of the relationship between the French-Canadian and the British is detailed. Robidoux's text takes a decidedly different approach. While his last words are indeed, "Vive la Reine," those words are not in English, thus breaking their emblematic significance (nor, incidently, is God invoked). In addition, these words are preceded by "Vive la France." 27 What Robidoux makes explicit is the imagined relationship between the French-Canadians and the Crown which permits the outpouring of devorion to the Queen. The Queen is understood both as the woman who wants "to be good" and as the embodiment of British liberty. She could not, therefore, act arbitrarily (as did her uncle, William IV, and her grandfather, George III, according to Robidoux). Citing the intervention of Monseigneur Forbin Janson (who pressed for the return from exile of the 1837 rebels), Robidoux argues that Victoria listened to her people, not to her ministers. Recalling the criticisms of the French-Canadians voiced by Lord Durham after the rebellions, Robidoux refutes Durham's accusation that they are an ignorant people who deserve to disappear. The achievements of individual politicians, from Papineau to Laurier, and of literary men and women, including poets, historians, and writers, are given as evidence of the progress of the race under the benificent rule of Victoria. It is this notion of progress - progress in political power, education and technological innovation of rail, communications and trade - which Robidoux attributes to the combined strength of the French spirit merged with British liberty and justice. Standing on the same platform at the same event, two politicians, one English, one French-Canadian, could articulate apparently contradictory interpretations of the significance of "God Save the Queen" which, nevertheless, confirmed the centrality of Victoria to the divergent interests of their multiple audiences.

\section{Advertising Nationalism}

The Jubilee Souvenir Number provides a visual demonstration of the narrative strategies which sustained the voices of seemingly disparate interests. Yet it also served to implicate one narrative thread into another so as to make it possible to support imperialist realities without destroying nationalist desires. The realism of LeVasseur's memory of the Rebellion as politically motivated and bloody would remind the contemporary French population that both the physical confrontation and the political situation had changed. Just as Robidoux points out, the exiles had been allowed to return to the embrace of "la patrie." 28 Laurier's ultimately 
unsuccessful attempt to placate the Nationalistes (a movement burgeoning under the influence of Henri Bourassa by the close of the century) and the English conservatives through a policy which supported British constitutional politics alongside Canadian economic self-determination, was at that moment seen to be working. This was evident at the national level in the popular delight at the reception of Laurier in London, where he had gone to attend the Colonial Conference which had been scheduled to coincide with the Jubilee. ${ }^{29}$ At the local level, the faith in Liberal progress as the tool of nationalism is widespread and evident in the extant literature. In what follows, I look at the ways in which the narrative threads of the Jubilee Souvenir Number mediate the different understandings of that Liberal vision. I then turn to consider the implications of those narratives which are not represented in the expected venues and consider how the absences or gaps in the record may provide the measure of success for the Liberal programme in Quebec in the 1890s.

The advertisements, forty-three in total, dominate eleven pages of the twenty-page brochure. Unlike similar contemporary pamphlets or souvenir albums, the advertisements do not follow a main body of text; they permeate it. ${ }^{30}$ Their storyline is as essential to the defining text of the Jubilee Souvenir Number as was the words of LeVasseur's commentary. Just as the symmetry of his text suggests equal status for the English- and French-language versions of the Jubilee story, so too the layout of the "commercial story" re-presents a natural symbiosis between the Crown and the city. The first two-page spread appearing after the title page contains two advertisements for large English-run companies. One is placed by Campbell and Brodie, a manufacturer of boots, shoes and rubbers. The other is for the Western Assurance Company (fig. 2). Both claim more than provincial status in their copy, with the first establishing its importation of products in addition to its manufacture; the second cites its international standing in England and New York, as well as Toronto and Quebec. As noted previously, the facing page depicts a full-length portrait of S.-N. Parent, Mayor of Quebec. English and French are balanced in the two-page spread by the doubled semantic value of the two advertisements against the singular presence of the full body of the French-Canadian Mayor.

If this visual weighting of the advertisements against images seems coincidental or imposed by my viewing, the next two-page spread suggests that the effect was intentional. If we can consider the represented image of the Mayor as representing the "textuality" of the French-Canadian presence, the following pages reiterate the verso/recto relationship of the two previous pages. Again, the advertisements are on the left and the "text" on the right (the "text" of the Mayor having been replaced by the "text" of the Jubilee; see fig. 3). Here the commercial statements are somewhat more complex in linguistic definition, as the advertisement for Le Magasin du Louvre, with a French-Canadian proprietor, A.N. Côté, uses English text to assert that business is booming ("Our Dress Goods Department is Booming! Our Gents' Furnishing Department is Booming!... Our low price pressure makes things boom all along the line"). ${ }^{31}$ Similarly complex is O. Picard \& Son's application of a rigorous bilingualism to their text, under an unilingual header, "[T] he hot water heating apparatus of the above building was installed by us." They explicitly draw the attention of the English audience to their commercial success in being the company chosen to heat the City Hall. Is this because the semantic value of the Hôtel-de-ville, a building constructed by a French-Canadian architect under the auspices of two French-Canadian mayors, is already tipping the two-page spread away from its careful equilibration of Canadian:British; French:English? Or is it merely that the Picards have every intention of installing a mechanical bell and a steam apparatus in as many English homes as possible? There is an argument for both motivations in that the former consideration of the placement of English and French text may be an implicit acknowledgement of the explicit desires of the financial community, which continuously strives to extend its client base, not only for profit, but also in the name of progress. This is a notion of progress as measured in terms both of personal success (the economy of individualism) and of the city as a whole in respect to its provincial and national competitors. The concern surrounding the expression of progress is clearly underlined by the claim of the printer of the Jubilee Souvenir Number to be "the only up-to-date plant in the city." ${ }^{2}$ The printer's halfpage advertisement is inserted on the horizontal between the second and third page. The location of this insert may have been a strategic gesture on the part of the printer, the Telegraph Job Printing Office, in that it breaks the orchestrated balance of the designed layout. Whether intentional or not, when the insert is turned over, its blank verso serves to erase the French name of Le Magasin du Louvre, the City Hall/ Hôtel-de-ville, and the name of the Picards. Thus it is impossible to see the Hôtel-de-ville at the same time as the images of Kensington Palace and Osborne House. The insert reasserts the emblematic and physical separation of the local from the monarchical. I am suggesting that it is this gap which is essential to the rationalization of the institutions of imperialism with the lived realities of "la patrie."

Before leaving the specifics of the advertisements, I would like to survey briefly the other juxtapositions which 
Figure 4. Quebec /ubilee Souvenir Number, (Quebec, 1897), pages 4-5 (Photo: John Briggs)

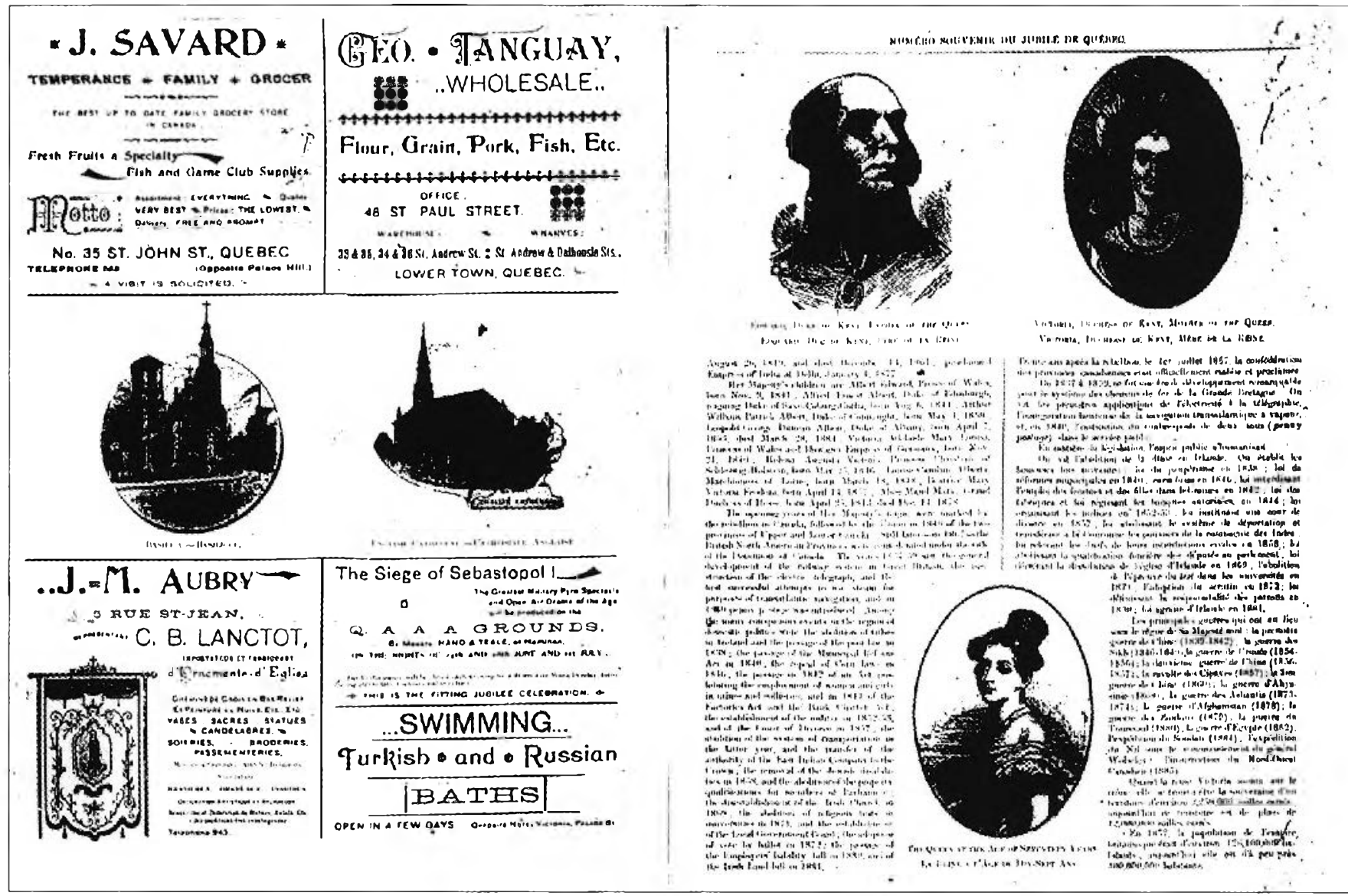

serve to define the modernity of the city of Quebec and its progress during the reign of Victoria. The two-page spread for pages four and five presents a complex design layout: the sexpartite division of page four features two advertisements on the upper third page, two images in the centre third, and two advertisemencs in the lower third; page five has three portrait cameos, two in the upper third and one centred in the lower third, with English and French text symmetrically arranged in the lower two-thirds of the page (fig. 4). Thus each page is harmonized internally as well as being balanced, but not symmetrical, over the two-page spread. In particular, the use of images on these two pages reinforces the relationship between Quebec and the Queen. The spiritual past and present of the city is signalled by the joint presence of the Roman Catholic Basilica and the English Cathedral on the page of advertisments. The recto images depict "Edward, Duke of Kent, Father of the Queen" next to "Victoria, Duchess of Kent, Mother of the Queen." At the apex of an inverse triangle is the image of "The Queen at the Age of Seventeen Years," i.e. at the moment before her accession to the throne. The images, then, present formative aspects of both the local and the imperial: the spiritual foundation of the nation and the Empire in the religious institutions of the ciry, and the moral upbringing of the Queen - a moral upbringing which, as Robidoux underlines in his discours de circonstance, was crucial to the formation of a monarch who refused the self-indulgence of previous kings, acted according to the motto, "I want to be good," and ensured the survival of both the French and English religious institutions of Quebec. Thus the visual narrative of these two pages supports the emblematic relationship between Crown and citizen. On the other hand, the verbal text writes the story of the immediate past in such a way as to heroicize both the Crown and the city. The achievements of the Crown are carefully delineated through an account of Victoria's personal, military, social and political accomplishments. Quebec City progress is marked by the advertisements for Savard's "Temperance * Family * Grocer" [!] with "the best up to date family grocery store in Canada," J.-M. Aubry's "Décorations Artistiques et Religieuses" (a man presumably resigned to a French Catholic audience with his advertisement entirely in French), Geo. Tanguay "Wholesale," and the soon to open "Turkish and Russian Baths." The advertisement for the 
open-air performance of "The Siege of Sebastopol" as the "Fitting Jubilee Celebration" provides an obvious inter-textual link to the list of "principal wars of the reign" which are detailed in LeVasseur's story of the reign (page five in French, "la guerre de Crimée", and top of page seven in English, "the Russian War, 1854-56"). I shall return to the Siege of Sebastopol below.

The multiple narratives of page four:five are similarly reiterated throughout the text. Pages six and seven continue the verbal narrative of achievements (Grenier's "Leading Quebec Grocer," Quebec's "Oldest Canadian Fire Office under Dominion License," LeVasseur's recitation of territorial and commercial expansion). Likewise, the visual narrative describes the history of French Canada through images of "Jacques Cartier Landing at Quebec" 33 and "Old St. Louis Gate" (bilingual captions are used to identify each of these historic sites) on the verso page which are positioned opposite three portraits of the Queen at eight, fifteen, and twenty-two years of age. The three portraits continue the visual narrative of preceding pages which illustrate the biography of the Queen; yet in isolation on the two-page spread, these same images function to signify the beginning of the reign in much the same way as the images of Old Quebec signal the rocts of contemporary Quebec, i.e. they both connote the passage of time by spotlighting unique moments in time (the "landing," "at age eight") and by presuming a natural progression across an unrepresented time line to the present. This inevitability of progress is reinforced in the specifics of LeVasseur's text, in which "the principal wars" are discussed unproblematically as fitting after the political history of the reign and before its commercial history. The brief history of the economic expansion of Canada, buttressed by convincing numerical detail, is offered as the inevitable consequence of the natural evolution of the reign: "[W]e had not one locomotive in Canada when Victoria came to the throne. Now we have 16,000 miles of railway, 1,948 engines, 2,058 passenger and baggage cars, and 56,929 freight cars carrying our goods and produce." It is no longer surprising that these details on page nine are prefaced by the paired images of "Château St. Louis en 1694" and a "Calèche Moderne," symbols of ancient and modern Quebec.

\section{Building a Narratıve}

The literal institutionalization of the monarchy informs a further visual storyline which is realized through the depiction of the Queen's official residences. The story of the buildings moves from the Queen's birthplace, Kensington Palace, through Osborne House, the country residence of the young royal couple, to Buckingham Palace. These images appear to be consciously used to mark the extremities of the Queen's biography. If, as I have argued above, the title page functions emblematically and the start of Victoria's personal narrative begins on page three after the representation of the Mayor, then the placement of the Queen's residences can be seen as marking the opening and closing of her personal story. Kensington Palace is the first to be illustrated, and is placed above Osborne House on page three. Page fifteen, the last page of written text (followed by three pages of advertisements) includes an illustration of Buckingham Palace, another of Balmoral Castle, and is flanked on page fourteen by an idyllic representation of Windsor Castle. Only Kensington Palace is referred to in the written text, and only then as the childhood playground of "Little Vic." Explanations are not necessary to the informed readers of this souvenir. Just so, an explanation of Quebec's architectural narrative would be superfluous: the image of the City Hall - Hôtel-de-ville naturally precedes the Queen's architectural narrative. The ongoing visuals of Quebec's churches and historic sites permeate and provide closure for the monarchical institutions. Presumably it is not coincidental that the last images of architectural sites are on page sixteen, after the final page of the Queen's biography. Thus it is the images of the "Old Hope Gate Ancienne Porte Hope" and "Martello Tower - Tour Martello," which follow those sites of Victoria's reign, that are structurally related to the rhetorical opening of Quebec's narrative as signalled in the singular image of the City Hall - Hôtel-de-ville.

\section{Gaps and Addenda}

Lest it appear that the entire publication exemplifies the hermetic resolution of all racial and economic tension in 1890s Quebec, it must be acknowledged that there is more English text than French in the Jubilee Souvenir Number. While the written text by LeVasseur appears in both languages with minor variations in wording which I have argued point to major variation in intent (as in the significance of "les troubles politiques et sanglants"), there are two additional pages of English text, unsigned, which follow LeVasseur's text. One focuses upon the international aspects of the Jubilee (page 13) and one upon the life of Victoria as a child (page 15). The latter page includes a paragraph on the re-enactment of the Siege of Sebastopol ${ }^{34}$ in a seemingly eclectic gesture not unlike the apparently random typesetting of contemporary journals in which an excerpt from a novella is followed by an extensive report on the Jubilee, which is in turn followed by the publication of a 
music recital. ${ }^{35}$ However, as mentioned earlier, the Siege was considered one of the most important battles of the Crimean War. ${ }^{36}$ Here it is described as "undoubtedly one of the most important events in the reign of Queen Victoria" (page 15). As a parallel to the Battle of the Plains of Abraham, itself the aftermath of a siege, Sebastopol returns the reader to a consideration of the fall which marked the shift from French to British rule - a shift which is cast as having productive consequences for the French-Canadians. In what is likely an unintended irony, the unidentified author of this brief paragraph concludes that the realism of the " 300 feet of scenery, over 100 uniformed soldiery... and all the din of the battle" make it "hard for the spectator to realize that what he sees is only Mimic War" (original emphasis). The spectator is permitted to vicariously relive the terror and chaos of the battle. Perhaps the advertisement and its placement serve as reminders of the historical distance which progress and civilization has provided between the Plains of Abraham and the Jubilee parade (and perhaps between the 1837 Rebellions and the 1897 Jubilee). As a mimic war, the representational status of the spectacle is acknowledged, but its realism may reside not in its reproduction of foreign events but in its evocation of memories of local chaos which preceded the calm of Victoria's reign.

Equally, the complex narratives which inform the $J u$ bilee Souvenir Number create an image of an entire population joined in one voice to cry "God Save the Queen." However, in realizing ourselves that as a representation the booklet employs the realism of local sites and concerns to appeal to the diversity of its audience, we can begin to open up the hermeneutic resolution of the dominant narrative. The complexity of the storylines is at least in some instances surely intentional. When LeVasseur does not provide simultaneously bilingual texts, he must be aware of the disparity. It is not only his use of different words to describe the same event (as in the Rebellion) which signals difference; there is also a lingering suspicion that local politics appear to dictate the necessary content of one version as opposed to the other. This is particularly evident in the displacement of LeVasseur's comments on the opening of Victoria Park which he uses in the second paragraph of his English version and which do not appear in the French version until the penultimate paragraph. It is with this discrepancy that I will conclude.

Not only does the reference to the Jubilee festivities in Quebec appear in very different locations in the two versions, but the festivities are also described in quite divergent fashions. Furthermore, as we have seen above, the two titles for the apparently bilingual text are not the same. The English version is headed by "Queen Victoria's Jubilee. Sixty
Years on the Throne;" the French title is, "Sa Majesté la Reine Victoria. Le Jubilé Royal à Québec." Once again employing an ironic twist in his first paragraph under the French rubric, LeVasseur commences with a fairly dry account of the accession of Victoria to the throne and immediately moves into a names-dates-and-event history. Thus, he totally ignores the actual local celebrations of "le Jubilé Royal à Québec" until his concluding paragraphs. His English version starts with two long paragraphs extolling the virtues of the "woman, wife, and mother, as well as the merits of the constitutional monarch." The celebration of the Diamond Jubilee is described not so much as the rejoicing of a great nation as it is "the acclaim by all races of a woman whose high station has given prominent display to those eminent virtues which command the respect of mankind." That this is not mere rhetoric or hyperbole is confirmed by the second paragraph which suggests that these sentiments are emphatically realized in Quebec:

In this feeling of personal loyalty and devotion, the Dominion of Canada is second to no part of the Empire, nor are the inhabitants of the old fortress of Quebec at all behind the rest of their Canadian fellow citizens. The French and English speaking sections are a unit in this and proof of the cordial feeling of the former is to be found in the contemplative change of the great national feast to Jubilee Day, when the opening of the Victoria Park, for which the cicy is indebted to its Mayor, Hon. Mr. Parent, will derive additional eclat from the annual procession of the St. Jean Baptistc Society. (p. 3)

I will argue that this paragraph is foregrounded in the English version as a necessary consequence of the desire to prove French loyalty. Furthermore, the French version of the local events is removed from the proximity of comparison to its location at the end of the text, and is significantly restructured, in order to reduce the significance of the role of the St. Jean Baptiste Society's compromise.

Parent is credited in English with his role in the opening of Victoria Park. Indeed, we have seen that he insisted on his name being replaced by that of the Queen. This is a rhetorical gesture we might recognize as self-effacement but what better replacement of the self could be desired than having one's shoes, so to speak, filled by the reigning monarch. Indeed, the fact that the Jubilee Parade had to approach Victoria Park by marching down Parent Boulevard could not be overlooked by the 20,000 parade spectators who followed the route to the Park's grandstand where the Queen's representative, the Lieutenant-Governor of Quebec, gave his speech. 
Despite the awkward phrasing, it is clear that for the English reader in Quebec the proof of French-Canadian cordiality lies in the decision of the St. Jean Baptiste Society to change the date of its annual procession to that of the Jubilee. This is exactly was is not included in LeVasseur's French version of the events. While he repeats the claim that French and English are united in their acclaim of the throne, he phrases it in such a way as to personify "Quebec" as the entity which sanctions unity, which participates in the Jubilee, and which addresses the throne. The shift from individuals, "the inhabitants of the old fortress of Quebec," to the singularity of "Quebec, the old fort, berçeau de la civilisation du nouveau monde" underlines the different orientation of the French-Canadians to the relationship between them and the Crown. The English presence in Quebec is subsumed in the totality of "Quebec" - a Liberal Quebec in which technological, social and political progress empowered it to "sanctionne l'union si désirable du Français et de l'Anglais." It is Quebec that chooses to accept the gracious sovereign; 37 "Québec éternisera le souvenir de la fête par l'inauguration solonnelle d'un parc public qui portera le nom de Victoria." This move to personify Quebec removes the discussion of personalities from the question of loyalty. Parent is not applauded but neither is the St. Jean Baptiste Society.

Although I have not been able to find any printed trace of resistance to the decision of the St. Jean Baptiste Society to combine its annual procession with the Jubilee parade, the absence of applause in LeVasseur's French version of the text suggests that there may have been some unspoken, or at least unrecorded, distaste. If there was only this absence in this text, it would not be possible to make this tentative suggestion. However, there is an extraordinary gap in the publication record of at least two journals which suggests that such "negative evidence" requires further consideration. Le Canadien Français and Le Jean-Baptiste had been published in Quebec on an annual basis on the occasion of St. Jean Baptiste Day. Both of these publications have a gap in publication in the $1890 \mathrm{~s}$. The former was published from 1889 to 1891 , inclusive; the latter from 1887 to 1892 , inclusive. Le Canadien Français resumed regular publication in 1899 and Le Jean-Baptiste in $1902 .{ }^{38}$ The lacunae in the publication records coincides quite closely with the rise of the Liberal Party in Quebec, and especially with the dates of Parent's mayoralty. Exceedingly popular according to contemporary accounts, the Liberal M.P. (from 1890), Parent was elected mayor in $1894 ; 3^{39}$ he became Premier of the province in 1900. Whether or not he was responsible for the gap in publication is not the issue (and certainly the existing archive does not reveal any such relationship).
However, his success was symptomatic of the weakness of the anti-Liberal, Nationaliste movement, which did not revive from its initial flourishing in the late 1880 s until Henri Bourassa gained a higher profile in the late 1890 s. What is significant is the gap itself. The absence of what might be the expected as the only contrary voice in the generalized adoration of the Queen looms large in the archive. Why did LeVasseur not mention Parent and the St. Jean Baptiste Society? Why did these two publications cease during Parent's tenure as Mayor?

One explanation of these absences is suggested, at least partially, in the existence of such public statements as the address of R.P. Boisseau, the General President of the St. Jean Baptiste Society, to Monseigneur Marois. Published in L'Évènement, one of the conservative French-language newspapers in Quebec at the time, Boisseau's address appears to be offered as an explanation for the decision to move the celebration of what is after all a Saint's Day Mass to the date of the Queen's Jubilee. ${ }^{40}$ Acknowledging the close bonds between "la Nationalité Canadienne-Française et la mère bien-aimée l'Église Catholique," Boisseau is careful to credit both the Church and the Sovereign for their roles in the advance of the French-Canadians. In particular, it is to the reign of Victoria that Boisseau credits "la réalisation de nos libertés constitutionnelles." This is why, according to Boisseau, the French-Canadians hold in their hands both the maple leaf and the rose (the emblems, respectively, of French Canada and Great Britain). The equally carefully worded response of Msgr. Marois to Boisseau's address, which was also published in L'Evènement, confirms the tacit agreement that Church and state, Roman Catholicism and Anglican Parliamentarianism, can work hand in hand.

This working relationship between nationalism, Catholicism and Liberalism was epitomized in the unprecedented integration of federal, provincial and municipal politics with nationalist sentiment in the St. Jean Baptiste Day Parade of 1896. In the year before the Jubilee, Wilfrid Laurier had chosen to signify the end of eighteen years of Conservative government and the inauguration of the first French-Canadian Prime Minister through his official participation in the $1896 \mathrm{St}$. Jean Baptiste celebrations in Quebec City. While the euphoria of union did not last beyond the end of the decade, ${ }^{41}$ it was an essential component of the French-Canadian conception of the relationship between Crown and nation in the 1890s. "La patrie" was reconcilable with British monarchy precisely because the institutions of the Crown were conceived of as matching the progressive intentions of a French-Canadian-dominated Liberalism (remember, for the first time in Canadian history, the Prime Minister, the Premier, the Mayors of Que- 
bec and Montreal, the Lieutenant-Governor, and the Provincial Secretary were all French-Canadians).

It is these relations which are represented in the Jubilee Souvenir Number. The nuances of different positionalities are addressed by the multiple strands of narrative. The visual narratives proffered through portraiture and city views create other texts which hover between the written and the imaged (and imagined). The full-length portrait of the Mayor, the Hon. Mr. Parent, inserted between the threequarter view of the Queen and the doubled account of the Jubilee, may serve to inscribe the sub-altern voice of the French-Canadian as emphatically as do the discrepancies in the written texts. Mediated by the visual archaeology of the page, the narratives of the images - and of the English- and French-language texts - can reveal subtle differences capable of satisfying contradictory views. However, there is a dominant narrative which suits, perhaps for different reasons, the purposes of its readers. While the English version of LeVasseur's text was not a rote translation, there can be little doubt that the multi-vocal exhortation of "God Save The Queen" was bilingual.

I would like to thank Annie Gerin for her prompt research assistance, and York University for making the Research Assistant position available to me. I would also like to thank Virginia McKendry and Richard Schneider for their critical feedback and editorial advice. The anonymous reviewer assigned to this paper by $R A C A R$ provided extremely useful and pointed critical comments for which I am grateful. This paper was presented in a much shorter and less developed format at the U.A.A.C. at Halifax in November 1994. Thanks are due to Brian Foss, Carol Zemel, Mary Sparling and other participants for their comments arising from the oral presentation. The permission to reproduce pages from the Jubilee Souvenir Album was given by the Musée de la civilisation, Archives du Séminaire de Québec.

1 Dorothy Thompson, Queen Victoria, Gender and Power (London, 1990), 128.

2 For more on the role of republican and imperial rhetoric in Britain during Victoria's reign, see Thompson, Queen Victoria, esp. chap. 5 - 7; E. Royle, Radical, Secularists and Republicans, 18661915 (Manchester, 1980); J.M. Mackenzie, Propaganda and Empire (Manchester, 1984). On the forms in which liberal and imperial discourse were present in Canada, especially in Quebec, during the last decades of the nineteenth century, see Gérard Bouchard, "Une nation, deux cultures. Continuités et ruptures dans la pensée qućbécoise traditionelle (1840-1960)", La construction d'une culture. Le Québec et l'Amérique française (Sainte-Foy, 1993), Paul-André Linteau, René Durocher, and Jean-Claudc Robert, Histoire du Québec contemporain, vol. I (Montreal, 1979), Susan Mann Trofimenkoff, The Dream of Nation. A Social and Intellectual History of Quebec (Toronto, 1983).
3 See Thompson, Queen Victoria, 134-36, in which she notes that the doubts were few and far between, and seemingly of litcle public consequence.

4 In using "French-Canadians" I am following contemporary usage in most English-and in some French-language publications of the 1890s. In referring to the native, French-speaking population of Quebec, local practice did not use "Québécois" as is common today. In Quebec City, "Canadien-Français" was beginning to displace "Canadien" which had dominated discussions of French-Canadian nationalism in the 1820s, for example. In Montreal, "Canadien" tends to dominate newspaper accounts, etc.

5 Quebec Jubilee Souvenir Number (Quebec, Telegraph Job Printing Office), June 1897.

6 Although I do not develop the gender or class stories here, I would not want to suggest that an all-male parade of workingclass to upper-class status functions benignly. I am working on the class divisions and oppositions in a manuscript which I am currently preparing for publication which was presented under the title, "The Body Corporate Gets a Wriggle On': Public Spectacle, Allegory and Symbolic Value in Montreal's Celebration of Victoria's Diamond Jubilee and St.-Jean-Baptiste Day, 1897" to the Canadian Historical Association, Montreal, August 1995.

7 The topos of the "ages of man" is suggested by this evolutionary profile of thc Queen's biography; that is to say, the Queen is not only a monarch, but a maturing individual, a mother, a "good woman," etc. Her biography represents her as ordinary, accessible and of the people. The "ages of man" cycle — birth through maturity and death - matches the "natural" evolution of the individual, of the seasons, of the day and aligns rhetorically with the "natural" evolution of the regime of power, the Imperial Monarchy. For variations on this theme, see Elizabeth Sears, The Ages of Man. Medieval Interpretations of the Life Cycle (Manchester, 1986). I am grateful to Richard Schneider for reminding me of this topos and for providing the reference. On the ways in which Victoria's gender contests this "ages of man" topos, see Lynda Nead, who argues that the category "woman" was constructed around a notion of women who did not mature, i.e. did not grow old or wise, Myths of Sexuality (Oxford, 1990), 14. On the view that Victoria should have retired when the Prince of Wales reached the age of majority, thus again suggesting that gender was problematic in the natural evolution of a monarch, see Thompson, Queen Victoria, 115.

8 The capacity of serial portraits to construct normative life stories is expanded upon in my discussion of the family portraits of Edward Onslow in "Narrating Personal Histories: The Case of Edward Onslow," Art History, 16:3 (1993), 408-23.

9 The Wickenden portrait still graces the halls of the Quebec City Hall. It was apparently used as the source of the bust portraits of Parent used to illustrate local advertising for the Quebec Bridge project.

10 See Les Maires de la Vielle Capitale, Québec (Québec, 1980), [p. 5]. 
11 See advertisement for the Quebec bridge, for example, which is illuminated with bust portraits in rondels of Laurier and Parent.

12 LeVasseur's name appears at the end of the French-language section of the story of the Jubilee. Identified as "N. LeVasseur," there is no doubt that the author of the text is Nazaire LeVasseur (1848-1927), a writer, journalist and Liberal Party member who became the Canadian Consul in Quebec for several South American countries.

13 Hayden White, "The Value of Narrativity in the Representation of Realicy," Critical Inquiry, 7 (1980), 57-27, esp. 26. White's contribution is particularly welcome as a way of re-framing nineteenth-century romanticized histories of nationhood. This is especially useful in looking at the single-author text. It becomes more problematic in the multiple-author "text" of the public event. I have drawn on White in a number of cases when discussing narrative structures and authorial intention, but in the case of the jubilee parade I find that the moralizing closure of narrative is undone by the multiplicity of contesting and reintegrating narratives of the souvenir album.

14 Peter Stallybrass and Allon White, The Politics and Poetics of Transgression (Ithaca, 1986), esp. 25-26, 191-202. Stallybrass and White substantially complexify the relations between high/low phenomena through their application of Bakhtinian dialogics. However, their maintenance of an underlying post-structuralist dichotomy, albeit one which acknowledges the temporary, transgressive nature of normative dialectics, or subtleties of performed meanings, tends to suggest a truth-by-opposition stance that places limits on interpretive strategies.

15 See Bhabha's formulations of sub-alternity and cultural hybridity as developed in such writings as "DissemiNation: Time, Narrative, and the Margins of the Modern Nation," Nation and Narration (London, 1990), 291-322; and The Location of Culture (London, 1994), esp. 192-193, 205-206. In the latter text, Bhabha extends the work of Veena Das and R. Guha on subaltern resistance, and suggests that the site of resistance/rebellion is not necessarily a form of negative opposition but of cultural hybridity (i.e. connoting agency on the part of the subaltern).

16 This is not a gratuitous observation, as Mayor Jean Drapeau's policy of placing Montreal in the international forum through the visibility of socio-cultural phenomena such as Expo ' 67 and "Floralie" of 1980 can be seen as somewhat akin to Parent's highprofile opening of Victoria Park (discussed below) and his grand socio-economic development projects like the building of the Quebec Bridge. Drapeau's desire to bring Montreal to international attention is evident in such comments as, "Montreal will be Rome." See Brian McKenna and Susan Purcell, Drapeau (Toronto, 1980).

17 N. LeVasseur, "Carneval 1996," Têtes et Figures (Quebec, 1920), 26-27. My translation.

18 I have not been able to confirm earlier publication of this story although it is quite plausible that it would have been published when LeVasseur was writing for L'Évènement during the 1880 s and 90 s.

19 "God Save the Queen" was regularly employed in French-language texts without translation into French, e.g., Le Courrier du Canada, 23 juin 1897 ("journal des intérêts Canadiens"). LeVasseur inserts "God save the Queen!" as a slogan/motto between the penultimate and final paragraphs of his text in the Jubilee Souvenir Number (p. 11) alchough he uses the French translation in the body of the paragraph.

20 The quotation from LeVasseur's story on "Carneval 1996" is explicit in crediting French as the "language of social, political and financial relations" even in Toronto where English has not disappeared but has been seen apparently as unable to compete with the efficacy of French as an administrative language of choice.

21 Minutes of the Municipal Council of 1897, published in Documents publié par ordre du Conseil de ville en vertu de la resolution du 18 juin, 1898 (Quebec, 1898). It is noteworthy that the minutes apparently were published to publicly confirm Parent's magnanimity and the importance of Victoria Park to Quebec. The publication includes the first council entries on the decision to buy the land, the name change, the speeches of the dignitaries who officiated at the opening of the Park, and the letters to and from the Queen and her representatives regarding permission to use her name.

22 Traditional rivalry between the two cities was accelerated during the years immediately preceding the Rebellion by Montrealbased calls for the union of Upper and Lower Canada, exacerbated by ongoing efforts to assert economic and social superiority, and maintained by personal polemics. For many years, the rivalries have been exemplified by the physical competition of the Canadiens and the Nordiques hockey teams.

23 Quebec Morning Chronicle, 23 June, 1897. Also advertised in other local papers, including the French-language journal Le Courrier du Canada.

24 The implication of the comment in the Jubilee Souvenir Number, p. 3, is that Parent was responsible for this date change. The credit for this manoeuvre is more generalized in the publication of the Jubilee programme by the St. Jean Baptiste Society of Quebec in which it is remarked that "the civic committee first obtained the support of the St. Jean Baptiste Society which graciously consented to advance by two days the celebration of the birthday of its Patron saint;" see Célébration à Québec du 60e anniversaire de l'heureux avènement de Sa Majesté la reine Victoria... (Quebec, 1897), p. 1.

25 Duffy's speech was not even included in the Municipal Council's publication of 1898 . However, the summary, which had been published in L'Evènement, 23 juin 1897, was included.

26 Ibid. English translations of the French summary of Duffy's speech are my own. "La belle bataille" has been translated as "the glorious battle."

27 L'Évènement, 23 juin 1897. The full text of Robidoux's speech was reprinted in several French-language newspapers, including 
Le Soleil, 23 juin 1897 (Le Soleil did not summarize Duffy's speech, although it did mention his "exceptional oration" and the "lively applause.") The conservative L'Évenement and the liberal Le Soleil were thus both seen to support Robidoux's vision.

28 "La patrie" is defined here as the mother country; literally, the place to which the exiled wished to return.

29 Laurier's visit to Great Britain was extensively commented upon in both English-and French-language newspapers. His presence at the Colonial Conference, in the Jubilee parade and at luncheons with various city officials was reported in detail, as was his speech to the conference participants.

30 Other Jubilee brochures typically contained advertisements but these were generally placed at the end of the primary text. The brochure publishing Montreal's Address to the Queen was virtually an advertisement in its entirety for Henry Birks and Sons; see, Canada to Her Queen (Montreal, 1897). It first describes the jewelled casket produced by Birks and Sons as a gift for the Queen and then reproduces the city's Address. However, the Diamond Jubilee Souvenir Official Programme for London, Ontario (1897?) does repeat the pattern of the Quebec Jubilee Souvenir Number.

31 The desire of the local businessmen to reach a wide audience is suggested by the use of the Americanism, "business is booming," which had only recently appeared in print (in American advertisements from 1879; OED). The expression specifically referred to the flourishing of business, the advancing on a tide of prosperity - a usage which confirms the notions of Liberal progress through economic, social and technical advances.

32 My argument here is that the significance of the printer was not that it was an English printer but that it was the most modern printer. While this was the printing plant of the English-language daily the Telegraph, the Telegraph Job Printing Office printed a variety of English- and French-language publications ranging from flyers to booklets. In 1894, the Telegraph Job Printing Office had published the carnival souvenir booklet in English and in French: Carnival Number of Quebec and Le Carnaval, both dated 29 January 1894.
33 Victoria Park incorporated the site of the "Landing of Jacques Cartier" in its grounds.

34 This passage functioned as an advertisement for the spectacle which was being produced by Messrs. Hand \& Teale of Hamilton, "the most remarkable open air drama of the age;" Jubilee Souvenir Number, 15.

35 As in Le Courrier du Canada, 23 juin 1897.

36 The battle had been the subject of similar scenic re-enactments in Canada, as in the "pyrotechnic" production displayed of the Siege of Sebastopol at the Industrial Exhibition in 1888 (CIHM 58713).

37 This relationship is similarly echoed in the expressed relationship between Canada and Great Britain which was voiced by Laurier during his Jubilee visit. "Replying to the saying that the British colonies are to become nations, [Laurier insisted that] Canada was a nation, that Canada was free.... [The Canadian people's] connection with Great Britain is that which they choose to maintain." Editorial for The Gazette, 21 June 1897, 4.

38 The papers did not establish long-running publication records. Le Jean-Baptiste was published irregularly until 1909 (1902, 03, 05, 09) and then more regularly after 1909. Le Canadien Français was published annually from 1899 to 1905 inclusive and irregularly after that.

39 Léon Lortie, Album Biographique des Membres du Conseil de Ville... (Quebec, 1897), unpaginated. Again Parent's biography is specifically tied to that of the Hôtel-de-ville as the Album Biographique contains the biographical data of the council members and the entrepreneurs of the new Hôtel-de-ville.

40 L'Évènement, 23 juin 1897.

41 Henri Bourassa, leader of the Nationalistes, was based in Montreal. His opposition to Laurier and the Liberal Party only relented somewhat between 1902 and 1908. Bourassa reconciled with Laurier after the 1902 Colonial Conference, given the latter's anti-imperialist stance on Canadian military involvement in the British armies, but the relationship was soured over the Naval Service Bill of 1908. 